\title{
INVESTIGATION ON CAUSES AND EFFECTS OF WATERLOGGING IN THE SOUTHERN PART OF BANGLADESH
}

\author{
Md. Shiblur Rahaman ${ }^{1,2 *}$, Nazmul Hossain ${ }^{1}$, Afrida Nurain ${ }^{3}$, Protima Sarker ${ }^{1,4}$ and Sahoko Ichihara ${ }^{2}$ \\ ${ }^{1}$ Department of Environmental Science and Disaster Management, Noakhali Science and Technology University, Noakhali-3814, \\ Bangladesh, shiblu@jichi.ac.jp; nazmulsheikhenv@gmail.com \\ ${ }^{2}$ Department of Environmental and Preventive Medicine, Jichi Medical University School of Medicine, 3311-1 Yakushiji, \\ Shimotsuke, Tochigi-329-0498, Japan, saho@jichi.ac.jp \\ ${ }^{3}$ Department of Environmental Sciences, Jahangirnagar University, Dhaka-1342, Bangladesh, afridanurain21@ gmail.com \\ ${ }^{4}$ School of Environmental Science, University of Shiga Prefecture, Hikone, Shiga 522-8533, Japan, protima_das37@ yahoo.com
}

\begin{abstract}
Noakhali Pourashava is an important municipality in southern Bangladesh, faces severe waterlogging problems every year during the monsoon period. The present study aimed to investigate the major causes of waterlogging and its negative effects on life, from the viewpoint of people residing in different areas of Noakhali Pourashava, various government, non-government, development organizations as well as various stakeholders including experts. It has been found that Noakhali Pourashava experienced waterlogging during peak monsoon season in ward no. 1,2, 4, 5, and 8. Most of the inhabitants/respondents of the Noakhali Pourashava claimed that lack of drainage facility; excessive rainfall; inadequate, low capacity and conventional drainage system; natural siltation; improper waste management; absence of proper inlets and outlets; and blockage and encroachment of existing drainage are responsible for waterlogging. It has ascertained that the water logging becomes a burden for the inhabitants of the Pourashava and creating adverse effects on livelihood, society, infrastructure, economy and environment. Other notable adverse effects of waterlogging are disruption of traffic movement and normal life, structures and infrastructure damage and loss of income potentials with a lot of sufferings. The stagnant water acts as a breeding site for the vectors of various diseases and becomes a health hazard to people residing in the waterlogged area. The current study suggests that close coordination among Pourashava authorities, local government agencies and a strong collaboration between public and private sectors as well as local people participation are essential for solving the waterlogging problem effectively and sustainably.
\end{abstract}

KEYWORDS: Waterlogging, Drainage system, Urban area, Livelihood, Sustainable solution.

\section{INTRODUCTION}

Bangladesh is a disaster-prone country which has a tropical monsoon climate characterized by heavy seasonal rainfall and the annual average precipitation is around $2320 \mathrm{~mm}$. Every year Bangladesh faces many natural and manmade disasters including floods. Recently, waterlogging becomes a great problem in urban areas of Bangladesh [1-3].

Waterlogging is not a local problem; it affects approximately $10 \%$ of the global land area and recently waterlogging also reported in Egypt [4-5], China [6-7], India [8], Australia [9], Africa [10], Vietnam [11] and so on.

In Bangladesh, the capital city Dhaka facing a severe waterlogging problem every year in the monsoon session [12]. Though Dhaka facing the worst waterlogging problem every year, other cities like Chittagong [13-14], Sylhet [15], Khulna [16], Pabna [3], Tangail [2], Jessore [17] Cox's Bazar [1] also facing this unpleasant problem. Bangladesh is one of the most densely populated countries in the world and experiencing severe environmental degradation due to rapid and unplanned urbanization and industrialization. The rate of urbanization and industrialization is used as an indicator for measuring the growth of the national economy, but rapid urbanization and industrialization have some negative effects and creating problems like traffic congestion, environmental pollution (air, water and soil), improper waste management, waterlogging, etc.

Waterlogging is considered as a bad outcome of technological and economic development especially in urban areas. When rapid urbanization is not managed properly it poses many challenges to city authorities and generates new problems like waterlogging. Not only big cities but also many districts of Bangladesh (especially 16 south-western coastal districts) are greatly affected by waterlogging and the people of affected areas are migrating to other places [18].

Topographically Noakhali is located in the coastal zone, the region is monotonously flat having low elevation. Noakhali faces a variety of socio-environmental challenges on a regular basis, among them waterlogging during the rainy season is considered as one of the major environmental threats and challenges. Waterlogging during peak monsoon sessions with high rainfall becomes a common phenomenon in the Noakhali Pourashava area (particularly in ward no 1,2, 4, 5 and 8) similar to many other urban areas of Bangladesh. The situation getting worse day by day due to the insufficient and unplanned drainage system. According to the Noakhali Pourashava, absence of an integrated network of secondary drains and roadside drains, blocking in the existing drains, absence of adequate roadside drains to drain out the runoff, gradual increases of the unplanned construction of residential, commercial buildings, hospitals, hotels, and restaurants along both sides of drains are the main cause of waterlogging in this area. This problem is also exaggerated by improper and careless disposal of solid waste and garbage into the existing drainage system.

Unplanned growth of urban infrastructure and inadequate management of existing drainage facilities may also worsen the issue of congestion even in relatively well-drained towns such as Sylhet [15]. Not only in Bangladesh, but other developing countries also suffering from such problems $[8,11,19]$. Even many modern cities in Europe and the US have some local problems on a smaller scale because their sewage networks lack 
enough capacity. However, some cities may have more significant problems, for example in Asia, since there are poor drainage systems and much heavier local rainfall. The problem is further exacerbated by the exponential development of Asian cities these days but without the funds required to improve and rehabilitate their current drainage systems [20].

In order to resolve the waterlogging problem of Noakhali Pourshava, it is important to figure out the inherent causes of this problem as well as its negative effects on human life. Therefore, the present study focuses to find out the root causes and major effects of waterlogging in Noakhali Pourashava as well as finding a sustainable solution to the waterlogging problem.

\section{METHODS AND MATERIALS}

\subsection{Description of the study area}

The Noakhali Pourashava is located in the southern part of Bangladesh under the Noakhali district between $23^{\circ} 17^{\prime}$ and $23^{\circ} 28^{\prime}$ North latitudes and between $89^{\circ} 55^{\prime}$ and $90^{\circ} 06^{\prime}$ East longitudes. The Pourashava is $187 \mathrm{~km}$ far away from the capital. It is bounded by Begumganj and Senbagh Upazila on the North, Hatia Upazila on the South. Companyganj and Sandwip Upazila on the East and Ramgati and Lakshmipur Sadar Upazila on the West. The total area of the Noakhali Pourashava is $15.88 \mathrm{sq} . \mathrm{km}$ (Figure 1). According to the census of 2011, the population of Noakhali Pourashava is around 1,00,219 with an average population density of 1565 per square kilometer [21].

\subsubsection{Climate and land use}

The average maximum temperature of Noakhali varies between $25.5{ }^{\circ} \mathrm{C}$ to $31.5{ }^{\circ} \mathrm{C}$, and the minimum temperature varies between $10.69^{\circ} \mathrm{C}$ (January) to $25.8^{\circ} \mathrm{C}$ (August). April to August are the hottest months in this area. On the other hand, cold periods start from November to February when the minimum temperature varies from $10.69{ }^{\circ} \mathrm{C}$ (January) to $18.1{ }^{\circ} \mathrm{C}$ (March). The average rainfall of Noakhali is $3451 \mathrm{~mm}$ in July, which is the highest among the rest months. It drops to $298.1 \mathrm{~mm}$ in September and further falls to $139.7 \mathrm{~mm}$ in October. From November to March, the rainfall varies between $29.6 \mathrm{~mm}$ to 33.1 $\mathrm{mm}$. The rainy season begins in April / May and usually ends at the end of October.

The existing land use is divided based on functional activities in the Noakhali Pourashava. In this Pourashava, agriculture, residential, and transport occupies 1144.87, 1750.21 and 605.281 acres of total land respectively. Besides, the area of the water body is about 8.41 acres.

\subsubsection{Drainage system and waterbodies}

The drainage channels within the Pourashava are composed of 8 canals/khals that are formed naturally. Generally, the canals are flowing towards North to South except the Noakhali Khal, which is moving towards south to north. The Khals are $17.6 \mathrm{~km}$ in length, which covers 71.244 acres of land. All the Khals are interconnected and flowing towards the Meghna river. Gabua khal is running towards Rahamatkhali Khal, which is connected to the Meghna river. Noakhali khal is also connected to the Meghna river through Wapda khal. Khal/canal, pond and ditch encompass 284.20 acres, which are $11.1 \%$ of the total area. Ward no. 3, 4 and 5 comprise 51.40, 55.90 and 49.20 acres, respectively.

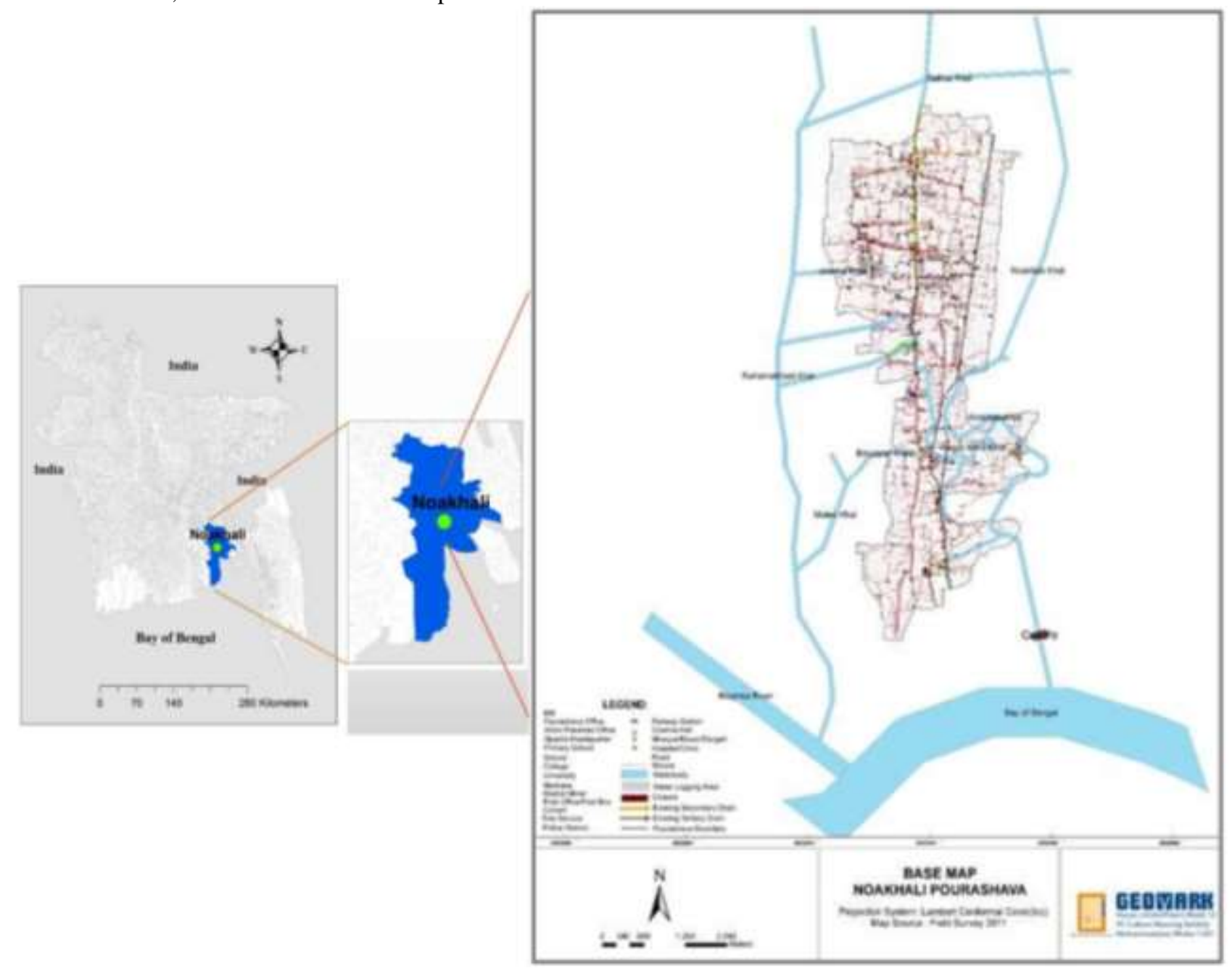

Figure 1. Map of the study area in Noakhali, Bangladesh. 


\subsubsection{Waterlogged areas}

Inundation within the Pourashava is experienced in the month of May to February (mid-Baishakh to Falgun in Bangla calendar). Though Noakhali Pourashava doesn't have any flood problems from the overflow of the khals/canals, most of the wards suffer from waterlogging due to heavy rainfall in the monsoon. This internal flood or waterlogging is experienced within ward no. 1, $2,4,5$, and 8 during peak monsoon time with high rainfall for a long duration.

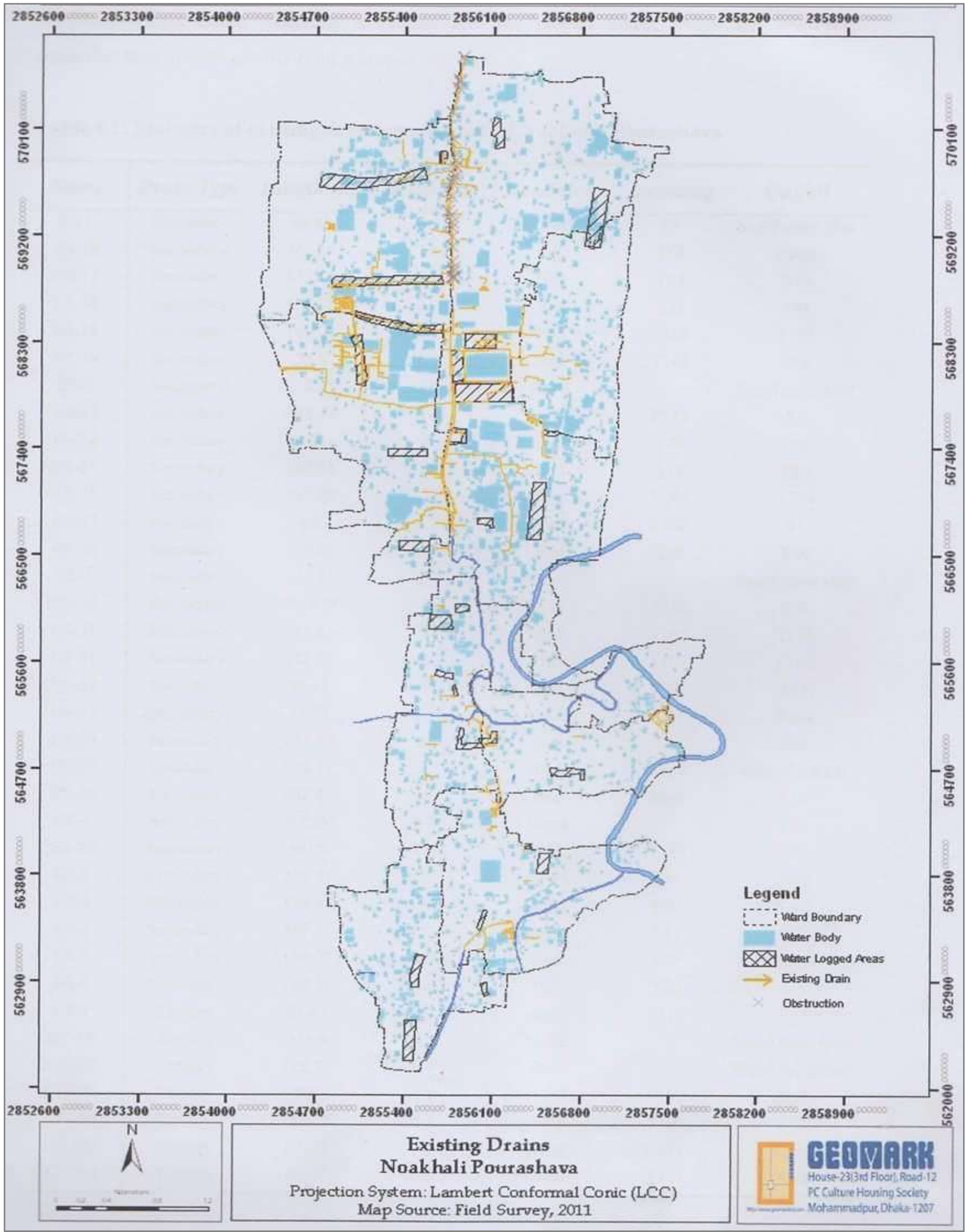

Figure 2. Existing Drainage Map of Noakhali Pourashava. (Source: Noakhali Pourashava).

In ward no. 1, along the kitchen market adjacent area, new police line road and new jail road, BADC, PWD adjacent areas become waterlogged. Waterlogged fields within ward no. 2 are Judge
Court area, D.C. office, SP office, and Gonopurta Bhavan adjacent areas. In ward no. 4, the Central road of Maijdee housing society and Dat bari have faced the obstacle. In ward 
no. 5, Khademul Islam road and Al-Amin guest house become waterlogged in the monsoon. Besides, Sonapur Islamia road and Ahmadia high school area in ward no. 8, also experience unusual waterlogging dilemmas.

\subsection{Data collection and analysis}

All the necessary data were collected from various sources, such as District Statistics 2011: Noakhali, Bangladesh Meteorological Department, and maps from the Noakhali Pourashava. To find out the inherent causes of waterlogging in the Noakhali Pourashava and its associated impact on city life, a questionnaire survey, informal interview and open discussion had taken among the authorities of diverse concerned organizations, experts and people living in different parts of the
Pourashava. The sample size of the survey activities was 100. It was also embraced the people's perception for sustainable development of the drainage system. The collected data analyzed by using Microsoft Excel and Arc GIS 10.8.

\section{RESULTS AND DISCUSSION}

\subsection{Causes of waterlogging}

For identifying the major causes of waterlogging in Noakhali Pourashava, a field survey in a form of a questionnaire survey (total respondents were 100), interviews (informal) and open discussion has been carried out with the authorities of different concerned organizations, experts and people living in different parts of the Pourashava areas.

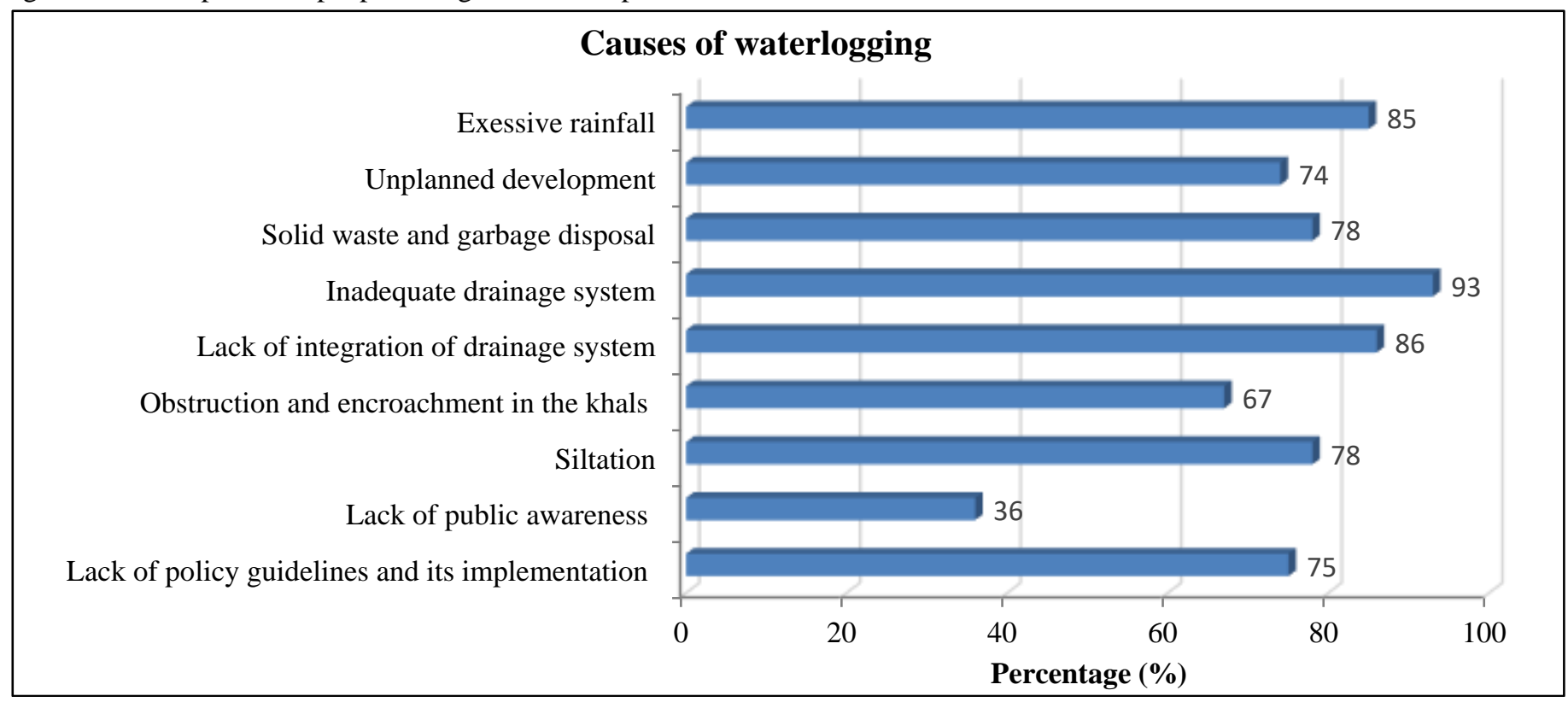

Figure 3. Causes of waterlogging in Noakhali Pourashava.

Based on the field survey, nine major causes were identified for the waterlogging in the Noakhali Pourashava. The major causes are excessive rainfall, population growth and unplanned development, solid waste and garbage disposal, lack of integration and proper drainage system, capacities and inadequate drainage system, siltation, obstruction and encroachment in the khals/canals, lack of public awareness, lack of regulation and its implementation (Figure 3).

\subsubsection{Excessive rainfall}

Heavy rainfall occurs in the Noakhali region because the Himalayas stands to the Northeast of Bangladesh, and the Bay of Bengal lies in the South part of the country. According to the questionnaire survey, 85 percent of the respondent has been considered heavy rainfall is one of the main causes of waterlogging in the Noakhali Pourashava. Throughout the monsoon, the intensity of rainfall is high, and the highest rainfall befalls in July (Figure 4).

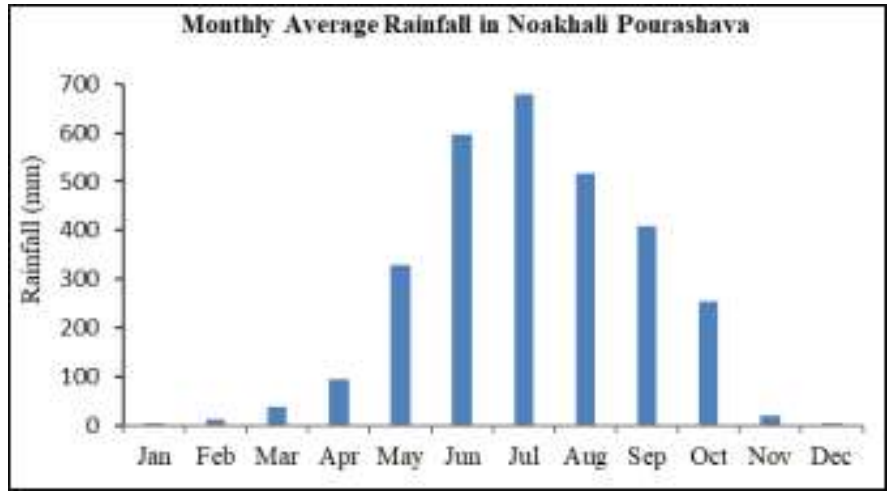

Figure 4. Monthly average rainfall in Noakhali Pourashava [22].

The Pourashava often becomes submerged because of the blockage of water at that time.

\subsubsection{Population growth and Unplanned development}

About $74 \%$ of the respondents claimed that unplanned development (urbanization) and the rapid population growth are mainly responsible for waterlogging in Noakhali Pourashava. The high-density population with the deficit of land creates extreme densification in the present congested areas. According to the assistant engineer of the Noakhali Pourashava accelerated population growth and landfilling without a proper plan for promoting new residential areas, uncontrolled and reckless disposal of solid wastes and litter into the existing drainage system, and encroachment on khals or canals with illegal construction are playing the influential part for waterlogging in this region. 


\subsubsection{Solid waste and garbage disposal}

The management of waste disposal system is a very important facility for the inhabitants to maintain a sustainable environment. In this Pourashava solid waste management is extremely poor and not adequate. In the issue of waste dumping, only $4.97 \%$ of the inhabitants of Noakhali Pourashava use dustbins. However, $78.35 \%$ of the residents dump their household waste beside their house. Only $1.35 \%$ of the residents dump their solid waste into the nearby canals. Dumping wastes adjacent to the house and in the khal/canal pollute soil and water. In the Noakhali Pourashava, some of the waste management activities are conducted by the local community-based organizations (CBOs). The waste collection action by the CBOs was observed in ward no. 1, 4, 5, and 9. The distance of the waste dumping place from the households was also considered. In most of the cases $(40.70 \%)$, the distance of solid waste dumping location from the residence was from 0.25 to $0.50 \mathrm{~km}$. It was also noticed that $35.9 \%$ of the dustbins are more than $0.5 \mathrm{~km}$ away from the house. Entirely $13.3 \%$ of residents had dustbins within $0.25 \mathrm{~km}$. In ward no. 9, it was ascertained that $98.56 \%$ of the houses have dustbins more than $0.5 \mathrm{~km}$ away from residence. Rainwater wiped away the trash and blockage the surface drains which impedes the natural flow of stormwater and creates waterlogging in various places of the municipality. According to the survey, $78 \%$ of inhabitants of this region declared that solid waste and garbage disposal are responsible for waterlogging.

\subsubsection{Lack of integration and poor drainage system}

The drainage network of Noakhali Pourashava is facing a lack of integration. In many parts of the Pourashava drains are found in a haphazard situation where integration among them is absent and the drainage design in Noakhali Pourashava somehow is not appropriate. Most of the drains were planned without maintaining a proper gradient which results in stagnant drains. According to the authority of Noakhali Pourashava, lack of integration and poor drainage system is one of the main reasons for waterlogging in this area. About $86 \%$ of inhabitants of this area claimed that the lack of integration and poor drainage system is responsible for waterlogging.

\subsubsection{Capacities and inadequate drainage system}

Most of the time it is observed that the average flood levels of the Pourashava area arise after heavy rainfall due to lack of timely drainage of water. As a result, waterlogging occurs in different parts of the Pourashava for the inadequate number of drains. In Noakhali Pourashava, normally there is no danger of intrusion of water from the Meghna river. In the Noakhali Pourashava area, the main drainage problem is the absence of adequate numbers of drains to carry the discharge into its outfall. The Pourashava is regularly affected as the existing drainage does not have enough capacity to drain the stormwater efficiently during the monsoon period. According to the survey, $93 \%$ of the respondent has been mentioned that capacities and inadequate drainage system is one of the main reasons for waterlogging in Noakhali Pourashava.

\subsubsection{Siltation}

It is worth mentioning that siltation plays a vital role in the waterlogging process in the natural drainage system. Rainwater carries out complex construction substances like bricks, sands and stones, household wastes, street sweepings and created favorable conditions for waterlogging by reducing the runoff capacity of the drainage system. Considerable siltation in the khals/canals in and around the Pourashava has taken place due to the expansion of the area over the last few decades. Around
78 percent of participants of the survey had stated siltation in the natural drainage system as a considerable cause for waterlogging.

\subsubsection{Obstruction and encroachment in the khals /drains}

Manmade obstacles on natural drains and encroachment in the khals accelerate the waterlogging condition. Gabua khal is acting vitally to carry out the maximum discharged water. Most of its parts are possessed illegally by placing box culverts and narrowing the channel and building concrete structures. As a result, its flow is becoming obstructed and failing to function properly. The absence of adequate roadside drains, lack of enough inlets to the secondary drains to carry stormwater and the obstruction and encroachment in the khals contribute to creating drainage congestion according to 67 percent of respondents of the survey.

\subsubsection{Lack of public awareness and education}

It was noticed that the dwellers of the Noakhali Pourashava are not aware and careful about the effect of drainage blockage and filling of natural drainage, lowlands, and wetlands. That is why they do not hesitate to dump/throw solid waste on the roads, drains and fill the natural water bodies. In this way, they are destroying ecological habitats due to their illiteracy. In order to save the cost of land acquisition for construction works, not just the general people but also the government authorities invade the wetlands, retention areas and khals. Subsequently, the waterlogging problem becomes more severe in the Noakhali Pourashava due to lack of public awareness and proper education. Based on the survey result, 36 percent of respondents claimed that lack of public awareness and proper education is one of the major causes of waterlogging. So, it is important to create public awareness to mitigate/solve the waterlogging problem in this region.

\subsubsection{Lack of Proper Policy Guidelines and its} Implementation

The lack of proper regulations and weaknesses in existing regulations are considered as a big gap for waste disposal, encroachment, negligence of the authorities for implementation. Sparse motive and public awareness to make the users responsible against clogging of the drains and encroachment of lowlands, wetlands, khals by individuals are the major reasons for the failure of the Pourashava to maintain the right approach over the existing natural drainage channels. About $74 \%$ of respondents claimed that the lack of suitable policy and its proper implementation intensifies the waterlogging situation.

\subsection{Effects of waterlogging}

In most of the cities in Bangladesh waterlogging becoming a common problem during monsoon sessions [23]. In most cases, the existing drainage system fails to carry out the urban runoff and creates the waterlogging problem. Natural drainage systems are disturbed by rapid urbanization. Unplanned urbanization also destroyed natural watercourses, decreases retention capacities as well as impermeable surfaces increases the amount of runoff. Excessive runoff is polluted by mixing with various contaminants, solid wastes, silts and accelerates the erosion and siltation process [12]. Waterlogging creates many problems and affects the normal life of the inhabitants of the Pourashava. For investigating the problem faced by the inhabitants of Noakhali Pourashava due to the waterlogging, field visit, questionnaire survey and the informal interview has performed, and gist of the opinions are presented in Figure 5. The waterlogging phenomenon negatively affects the normal life of the inhabitants 
of the Pourasava and creates social, environmental, and economic problems.

\subsubsection{Social problems}

Waterlogging seriously disrupts the normal life of the residences of Pourashava, and it has direct impacts on the poor people, and they suffer the most. Waterlogging disrupts normal life, traffic movement, causes damage to roads, houses, as well as hamper the education system. According to the survey, about 90 percent of responders said that waterlogging disrupts their normal lifestyle and 81 percent of people claimed that waterlogging disrupts the normal traffic movement of the Pourashava area. Waterlogging creates roads unusable for pedestrians also creates traffic jams. In traffic jams, many people waste their valuable time and can't reach their working place or school timely. About 78 percent of interviewers said that waterlogging causes damage to roads and 67 percent of people claimed that it causes damage to households or household goods (Figure 5). Waterlogging also hampering the education system, because some schools and colleges also facing waterlogging problems and unable to perform normal educational activities. About 70 percent of responders claim that waterlogging severely hampering the education system.

\subsubsection{Environmental Problems}

Drains of Noakhali Pourashava carry both types of stormwater and wastewater and mix up with each other which causes severe water pollution in the Pourashava area (especially in low-lying areas, khals, ponds). According to survey results, $85 \%$ of residents claimed that stormwater of Noakhali Pourashava is polluted by the mixing with the solid waste, clinical waste, hospital waste, silt, contaminants, domestic wastewater, and other human activities, which further contaminated groundwater as well as the receiving water bodies. This polluted stagnant water often creates a bad odor, acts as breeding sites for various diseases-causing vectors (e.g: mosquito), spread waterborne diseases. About 87 percent of responders said that waterlogging increases mosquitos and 82 percent of people claimed that it increases waterborne diseases (Figure 5). Among all the environmental problems associated with waterlogging, damage to vegetation (both agricultural and nonagricultural) and aquatic faunas are most alarming. Long term water stagnancy negatively affects the habitat of natural fauna and floras. Sometimes the death of fishes was also noticed and about 39 percent of responders claimed that waterlogging damages natural vegetation as well as agricultural vegetation.

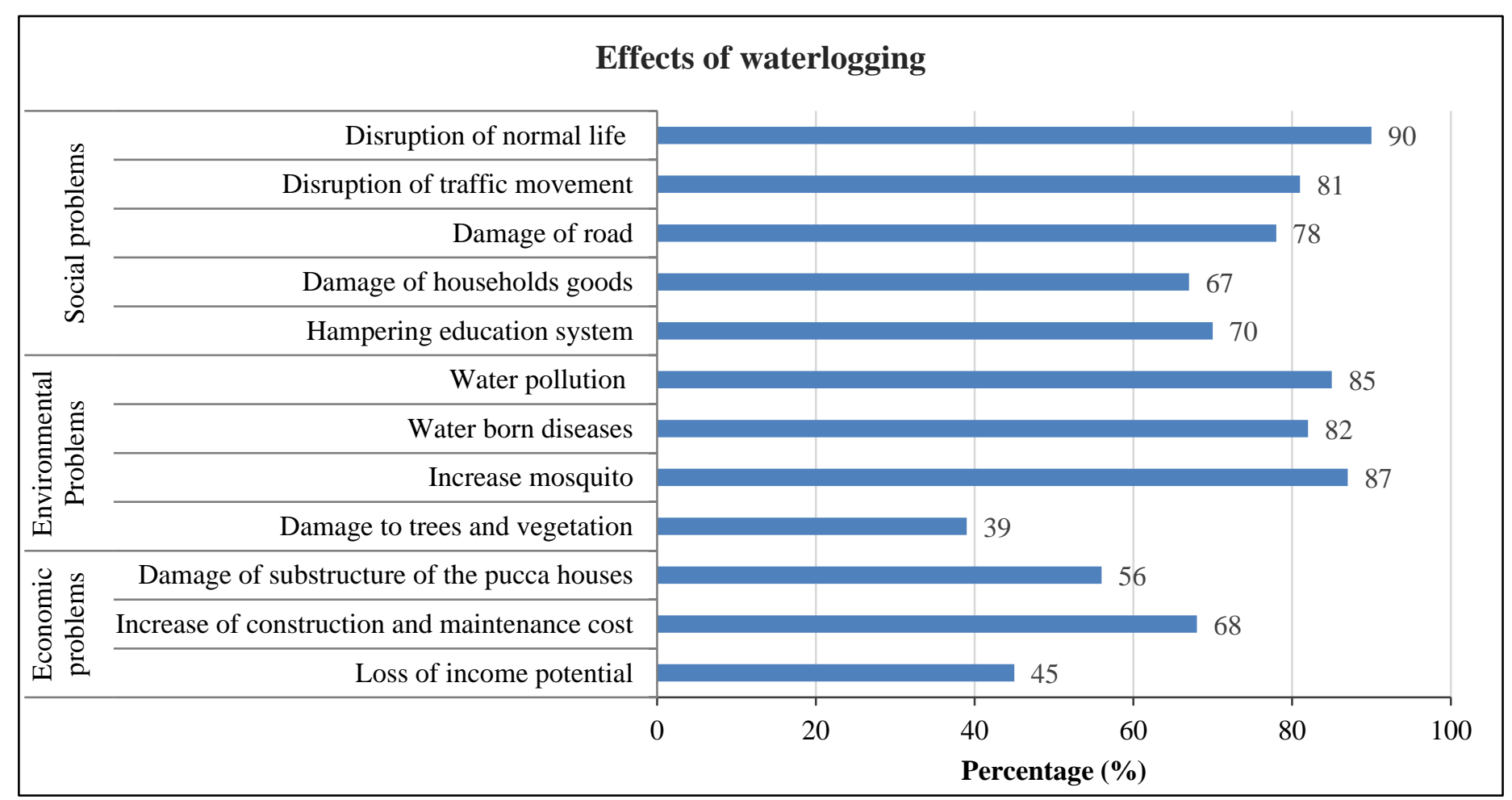

Figure 5. Negative effects of waterlogging in Noakhali Pourashava.

\subsubsection{Economic problems}

Waterlogging is a recurrent problem in most of the cities in Bangladesh during the monsoon session due to heavy rainfall. Waterlogging causes many serious problems including social, environmental, physical, and economic problems (Figure 5). About 45 percent of interviewers claimed that waterlogging severely affects people's daily incomes. The direct sufferers are rickshaw puller, street vendors and daily laborers. Waterlogging situation drastically cuts their daily income. Not only the income of general people, but waterlogging also increases the cost of construction and maintenance of roads, houses, and other vulnerable infrastructures. Because of waterlogging, the substructure of the buildings in the low-lying areas remains submerged. The brick foundations lose their longevity by being impacted by the corrosive salinity effect and dampness. Many buildings are seriously damaged during the period of waterlogging and sometimes it damages the household goods and stored food grains. About 56 percent of responders stated the damage of houses, substructure of houses and household goods due to prolonged waterlogging. Waterlogging raises the cost of repair and maintenance, $68 \%$ of respondents claimed. As stated earlier, waterlogging reduces the longevity of infrastructures and causes the damage of various underground utility services such as water, gas, telephone sewerage as well as entails a large expense which raises the cost of maintenance for the authority and inhabitants.

\section{CONCLUSION AND RECOMMENDATIONS}

Waterlogging has become a severe problem in Noakhali Purashava which has many negative impacts on livelihood. Waterlogging in the Noakhali Pourashava area is the outcome of 
unplanned rapid development. The situation worsens due to the unplanned construction, inadequate drainage system and improper waste management. The present study found that the waterlogging problem could be overcome by using proper drainage systems. Most of the interviewers and experts also claimed that a proper drainage system and their regular maintenance and monitoring can drastically solve the waterlogging problems in this area. A sustainable solution to the waterlogging problem in Noakhali Pourashava is proposed in this study where strong coordination among concerned authorities and organizations, local people participation and regular maintenance and monitoring are considered as an effective management tool (Figure 6). Some important recommendations for solving the waterlogging problems in Noakhali Pourashava in a sustainable way are also discussed.
> The establishment of strong coordination among government organizations is very essential.

$>$ In each and every stage of proper drainage management and implementation, local people and stakeholder's participation should be ensured.

$>$ For the proper functioning of the drainage system, it is essential to have an appropriate maintenance program. The program must include regular inspection/monitoring, enforcement, cleaning and repair. Drains should be cleaned once per month, but not less frequently than once per three months.

$>$ A proper and complete waste management guideline should formulate by the Pourashava authority.

$>$ The existing khals (canal/drains) should free from illegal encroachment and need to construct some new drains (secondary and tertiary) with a proper plan (Master plan).

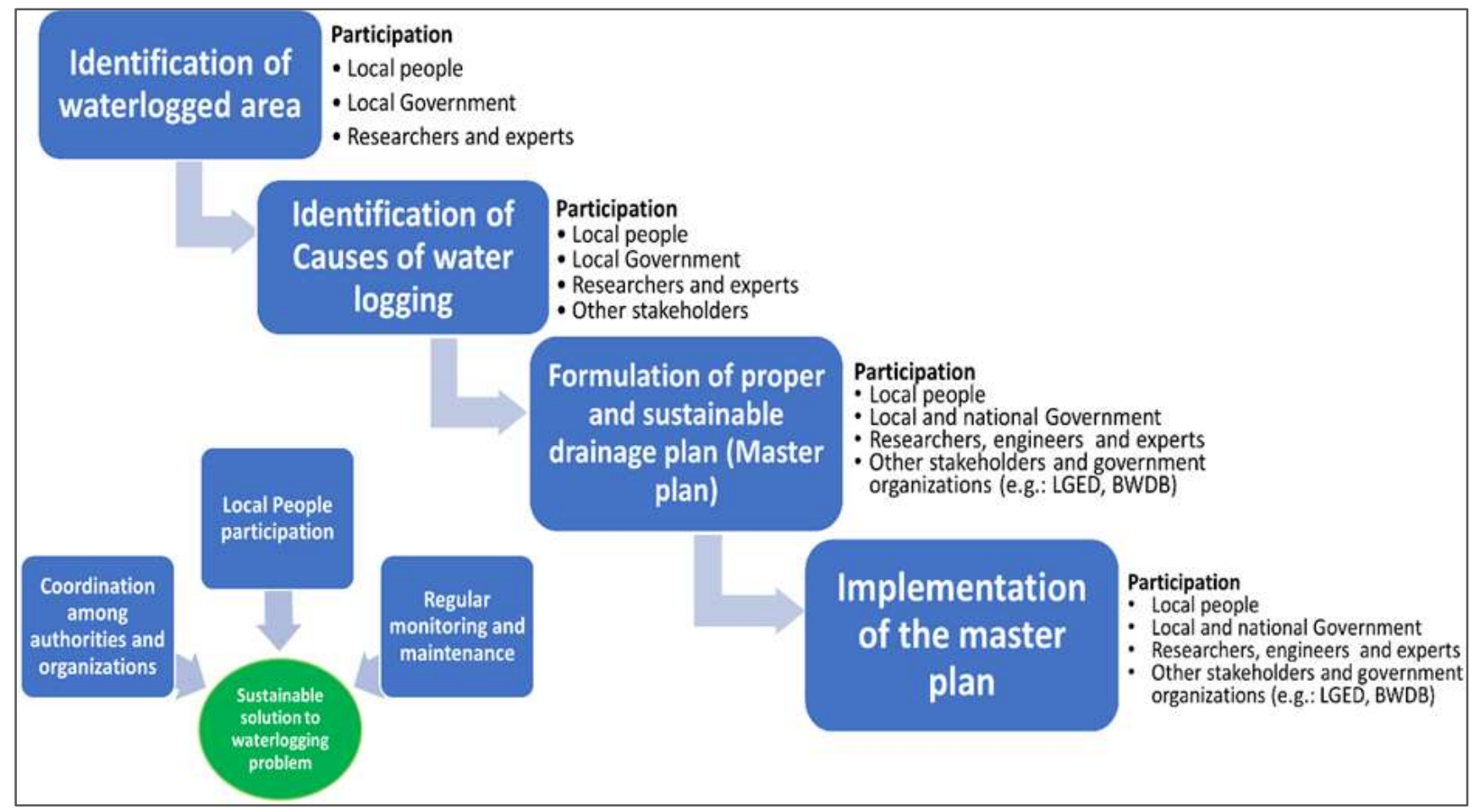

Figure 6. Flow diagram of a sustainable solution to the waterlogging problem.

$>$ Creating public awareness through the launching of community participation program by motivating the community through campaigns for keeping the Pourashava neat and clean, educating the school children from a primary level about town cleaning, disposal system of waste and knowledge on health and hygiene, diseases and impacts on the environment.

$>$ Above all, need practical and feasible rules and regulations for managing the drainage systems properly as a legal instrument.

\section{REFERENCES}

1. Anisha, N. F. and Hossain, S. A Case Study on Water Logging Problems in an Urban Area of Bangladesh and Probable Analytical Solutions, 2nd International Conference on Advances in Civil Engineering, CUET, Chittagong, Bangladesh, (2014).

2. Latif, M.B., Arifujjaman, M., Siddick, M.Z. and M.E. Effect of waterlogging in Tangail Paurashava. Journal of Science and Technology, 6 (1 \& 2): 11-20, (2016).
3. Hasan, M.R. Hossain, M.T. Khan, L.A. and Afrin, S. Seasonal water logging problem in an urban area of Bangladesh: A study on Pabna Pourashava. 1st National Conference on Water Resources Engineering (NCWRE 2018), 21-22 March 2018, CUET, Chittagong, Bangladesh. Paper ID: 098, (2018).

4. Awad, S.R. and Fakharany, Z.M.E. Mitigation of waterlogging problem in El-Salhiya area, Egypt. Water

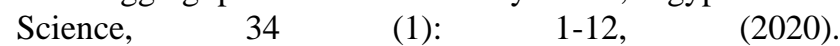
https://doi.org/10.1080/11104929.2019.1709298

5. Kaiser, M. F., El Rayes, A., Ghodeif, K. and Geriesh, B. GIS data integration to manage waterlogging problem on the eastern Nile delta of Egypt. International Journal of Geosciences,s 4(4), 680, (2013).

6. Sang, Y.F. and Yang, M. Urban waterlogs control in China: more effective strategies and actions are needed. Nat Hazards 85, 1291-1294, (2017). https://doi.org/10.1007/s11069-016-2614-4

7. Yong, S. H., Shiyuan, X., Chun, S. H., A-li, S. U. N. and Qing-liang, Z. H. A. O. Risk assessment of rainstorm waterlogging on old-style residences downtown in 
Shanghai based on scenario simulation. Journal of natural disasters, 3, (2011).

8. Roy, R. and Dhali, M. K. Seasonal Water logging Problem in A Mega City: A Study of Kolkata, India. Journal of Research in Humanities and Social Science, 4 (4): 01-09, (2016).

9. Cox, J. W. and McFarlane, D. J. The causes of waterlogging in shallow soils and their drainage in southwestern Australia. Journal of Hydrology, 167(4), 175-194, (1995). https://doi.org/10.1016/0022-1694(94)02614-H

10. Ojo, O. I., Ochieng, G. M. and Otieno, F. O. A. Assessment of water logging and salinity problems in South Africa: an overview of Vaal Harts irrigation scheme. Water and Society, 153, 477, (2012).

11. Tran, D., Xu, D., Vanha Dang, V. and Alwah, A.A.Q. Predicting Urban Waterlogging Risks by Regression Models and Internet Open-Data Sources. Water, 12(3), 879, (2020). https://doi.org/10.3390/w12030879

12. Tawhid., K. G. Causes and effects of water logging in Dhaka City, Bangladesh. Master thesis, Department of Land and Water Resource Engineering, Royal Institute of Technology, Stockholm, (2004).

13. Papry, R. I. and Ahmed, G. U. Drainage Condition in Water Logged Areas of Central Part in Chittagong City Corporation. International Journal of Engineering Science Invention. 4 (1): 24-29, (2015).

14. Akter, A., Mohit, S.A. and Chowdhury, M.A.H. Predicting urban storm waterlogging for Chittagong city in Bangladesh. International Journal of Sustainable Built Environment, 6(1): 238-249, (2017). https://doi.org/10.1016/j.ijsbe.2017.01.005

15. Ahmed, S.S. State of Drainage Congestion in Sylhet City, Bhugal Patrika, 28: 61-74. Department of Geography and Environment, Jahangirnagar University, Savar, Dhaka, (2009).
16. Rahman, M. M. Akteruzzaman, A. K. M. Khan, M. M. H. Jobber, A. and Rahman, M. Analysis of waterlogging problem and its environmental effects using GIS approaches in Khulna City of Bangladesh. Journal of Socioeconomic Research and Development, 6(2): 572-577, (2009).

17. Adri, N. and Islam, I. Water Logging in Keshanbpur: A Focus to the Coping Strategies of the People. In Proceedings of International Conference on Environmental aspects of Bangladesh (ICEAB 10): 33-36, (2010).

18. Rahman, K. A. and Debnath, S. C. Water Logging and Losses in Ecosystem: A Case Analysis on DND Embankment, Bangladesh. International Research Journal of Interdisciplinary \& Multidisciplinary Studies (IRJIMS), 27-33, (2015).

19. Singh, N. Need for environmentally Sustainable Development Plan: Special Reference to case of River Yamuna in Delhi. ITPI Journal, 1, 4, (2004).

20. Danish Hydraulic Institute (DHI). Urban Drainage Modeling, A collection of experiences from the past decades, 2002.

21. Population Census 2011: Noakhali. Bangladesh Bureau of Statistics. http://203.112.218.66/WebTestApplication/userfiles/Image /Census2011/Chittagong/Noakhali/Noakhali_C01.pdf

22. Bangladesh Meteorological Department, Noakhali, http://live3.bmd.gov.bd/

23. Subrina, S. and Chowdhury, F.K. Urban dynamics: An undervalued issue for water logging disaster risk management in case of Dhaka city, Bangladesh. Procedia Eng. 2018, 212, 801-808, (2018). https://doi.org/10.1016/j.proeng.2018.01.103 